\title{
Pre-industrial and mid-Pliocene simulations with NorESM-L: AGCM simulations
}

\author{
Z. Zhang ${ }^{1,2,3}$ and Q. Yan $^{3}$ \\ ${ }^{1}$ Bjerknes Centre for Climate Research, Allegaten 55, 5007, Bergen, Norway \\ ${ }^{2}$ UNI Research, Allegaten 55, 5007, Bergen, Norway \\ ${ }^{3}$ Nansen-Zhu International Research Center, Institute of Atmospheric Physics, Chinese Academy of Sciences, \\ 100029, Beijing, China
}

Correspondence to: Z. Zhang (zhongshi.zhang@bjerknes.uib.no)

Received: 18 April 2012 - Published in Geosci. Model Dev. Discuss.: 9 May 2012

Revised: 10 July 2012 - Accepted: 20 July 2012 - Published: 21 August 2012

\begin{abstract}
In the Pliocene Model Intercomparison Project (PlioMIP), two sets of experiments are suggested. One includes a reference and a mid-Pliocene experiment run with atmosphere general circulation models (AGCM experiments, referred to as Experiments I), the other includes a pre-industrial and a mid-Pliocene experiment run with coupled ocean-atmosphere general circulation models (AOGCM experiments, referred to as Experiments II). In this paper, we describe the AGCM experiments with the atmosphere component in the low-resolution version of the Norwegian Earth System Model (NorESM-L), and also assess the potential uncertainties in analyzing mid-Pliocene climate anomalies that might result from the choice of the sea surface temperature (SST) forcing for the reference experiment (pre-industrial or modern). We carry out a mid-Pliocene experiment, a control experiment forced by the modern SST fields, and a pre-industrial experiment forced by the monthly SST fields from HadISST averaged between 1879 and 1900. Our experiments illustrate that the simulated mid-Pliocene global mean annual surface air temperature (SAT) is $17.1^{\circ} \mathrm{C}$. It is $2.5^{\circ} \mathrm{C}$ warmer than the control experiment, but $2.7^{\circ} \mathrm{C}$ warmer than the pre-industrial experiment. We find that the uncertainties in analyses of mid-Pliocene climate anomalies are small on a global scale, but still large on a regional scale. On the regional scale, these uncertainties should be noted and assessed in future PlioMIP studies.
\end{abstract}

\section{Introduction}

The mid-Pliocene period, the most recent period in Earth's history, is thought to be a potential analog for the long-term fate of the climate system in the coming future (e.g. Jansen et al., 2007; Dowsett et al., 2010; Meehl et al., 2007). It has been a focus for geological (e.g. Dowsett et al., 1992, 1994, 1996, 1999, 2009, 2010) and modeling (e.g. Chandler et al., 1994; Sloan et al., 1996; Haywood et al., 2000; Haywood and Valdes, 2004; Jiang et al., 2005; Yan et al., 2011) studies for more than one decade.

As a potential analog for the coming future, more attention is being paid to the mid-Pliocene warm period. A recent midPliocene simulation (Lunt et al., 2010) and reconstruction of $\mathrm{pCO}_{2}$ in the Pliocene (Pagani et al., 2009) indicate that climate sensitivity to the Earth system feedbacks is larger than climate sensitivity to the fast feedbacks. $\delta^{18} \mathrm{O}$ records from coral skeletons found in Philippines demonstrate that permanent El Niño conditions did not exist during the Pliocene warm period (Watanabe et al., 2011). New sensitivity analyses (Lunt et al., 2012) indicate that the elevated atmospheric $\mathrm{CO}_{2}$ level is the main reason for the warm mid-Pliocene climate on a global scale. On a regional scale, ice sheet retreat and decrease in topography caused by the ice sheets retreat are the major reasons for the stronger warming at high latitudes in the mid-Pliocene.

In order to better understand the dynamics behind the mid-Pliocene warm climate, and to further reduce gaps between simulations and reconstructions, the Pliocene Model Intercomparison Project (PlioMIP) has been recently 


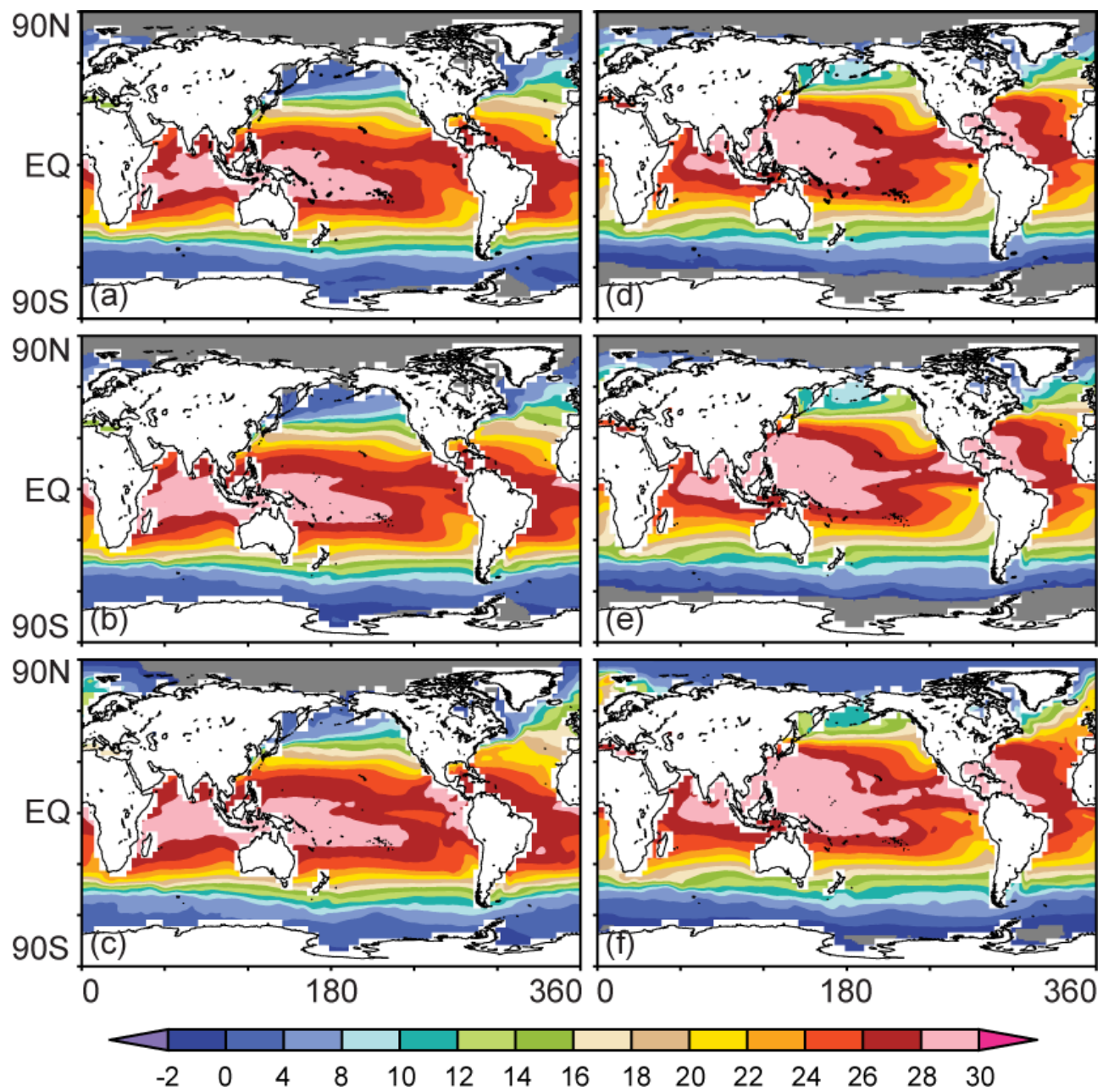

Fig. 1. SST $\left({ }^{\circ} \mathrm{C}\right)$ and sea-ice fields used in the experiments, left column for February, and right column for August. (a) and (d) for monthly mean HadISST between 1879-1900. (b) and (e) for local modern SST. (c) and (f) for mid-Pliocene SST. Gray represents the area covered by sea-ice.

initiated (Haywood et al., 2010, 2011). Within the PlioMIP framework, an increasing number of mid-Pliocene simulations (e.g. Chan et al., 2011; Koenig et al., 2012; Yan et al., 2012; Zhang et al., 2012) are being published. According to the PlioMIP experimental guidelines, two sets of experiments should be conducted based on the PRISM (Pliocene Research, Interpretation and Synoptic Mapping) reconstructions (Dowsett et al., 2010). The first set includes a reference and a mid-Pliocene experiment run with atmosphere-only climate models (AGCM experiments, referred to as Experiments I). The second set includes a pre-industrial and a midPliocene experiment run with coupled ocean-atmosphere climate models (AOGCM experiments, referred to as Experiments II).

Here, we describe the reference and mid-Pliocene experiments with the atmosphere component of the low-resolution version of the Norwegian Earth System Model (NorESM-L), Community Atmosphere Model version 4 (CAM4). The sim- ulations with the coupled NorESM-L have been described by Zhang et al. (2012).

As the PlioMIP experimental guidelines suggest, the reference experiment is called pre-industrial experiment, but carried out based on local modern SST fields (Haywood et al., 2010). However, due to the increased greenhouse gas levels since the pre-industrial, modern SSTs are warmer than the pre-industrial. Whether the utilization of modern SSTs largely underestimates the climate anomalies between the mid-Pliocene and the pre-industrial is not assessed. Thus, in this paper, we also consider the potential influence of SST fields used in the reference experiment in analyses of the mid-Pliocene climate anomalies.

The experiments presented in the paper are contributions from the Bjerknes Centre for Climate Research (BCCR) and the Norwegian Climate Centre (NCC) to the PlioMIP Experiments I. Section 2 introduces the CAM4 model. In addition to the information that has already been given by Zhang et 

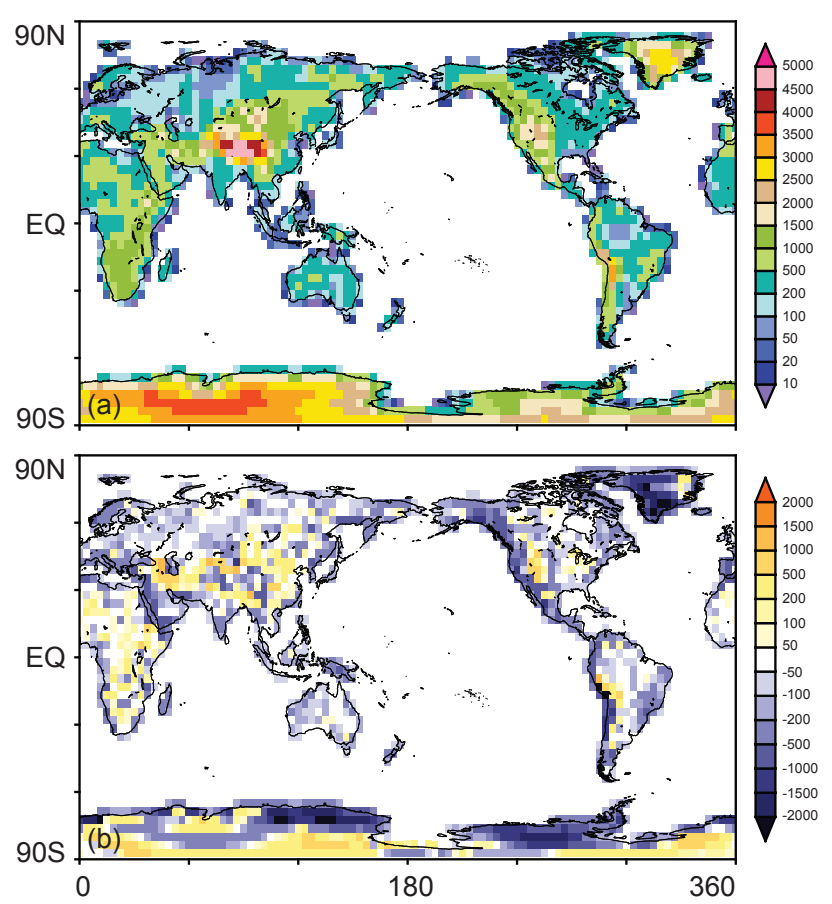

Fig. 2. Topography (m) conditions used in the experiments, (a) for local modern topography, (b) for the topography difference used to create the mid-Pliocene topography.

al. (2012), in Sect. 3 we present details on the source and implementation of the boundary conditions (including SSTs, topography, vegetation and ice-sheets) that have been used in the PlioMIP simulations. Section 4 gives an overview on general results of the climate simulations. In Sect. 5 we conclude with a general discussion and summary.

\section{Model description}

The model used in this study is the spectral version of the Community Atmosphere Model CAM4 (Neale et al., 2010; Eaton, 2010), which was developed at the National Center for Atmospheric Research (NCAR). The resolution used for the model CAM4 is T31 in the horizontal, approximately 3.75 degrees, and 26 levels in the vertical. This model is exactly the same as that used in the coupled simulations, and has been introduced by Zhang et al. (2012). Two parameters that are special to the NorESM-L are described here: the minimum relative humidity for low (cldfrc_rhminl) and for high (cldfrc rhminh) stable clouds. Tuning of these two parameters can reduce cooling bias in simulations with the default parameters taken from the low-resolution version of Community Earth System Model (CESM) or Community Climate System Mode, version 4 (CCSM4), and thus make simulations more realistic. In the coupled simulation with NorESM-L (Zhang et al., 2012), we find that the cldfrc_rhminl set to 0.835 and the cldfrc_rhminh set to 0.800 are the best options. Other parameters are set to the default values for pre-industrial simulation with the CAM4. More information about the CAM4 is given by Neale et al. (2010), and in the user guide (Eaton, 2010) and the model validation paper for the low-resolution version of CCSM4 (Shields et al., 2012). Detailed introductions to the NorESM are provided by Alterskjær et al. (2011) and Zhang et al. (2012).

\section{Boundary conditions and experimental designs}

\subsection{SST and sea ice}

Following the PlioMIP experimental guidelines (Haywood, et al., 2010), local modern SST and sea-ice fields should be used in the reference experiment. Our local modern SST and sea-ice fields (Fig. 1b, e) are created by Hurrell (2005), based on the Hadley Center SST anomalies with the Reynolds SST climatology. They represent the situations for 2000s, which are warmer than pre-industrial SSTs. Thus, we choose the monthly mean SSTs from 1870-1900 HadISST to create the pre-industrial SSTs. The pre-industrial SST fields (Fig. 1a, d) are created with the anomaly method (Eq. 1) similar to the one suggested by the PlioMIP experimental guidelines (Haywood, et al., 2010).

$$
\begin{aligned}
& \mathrm{SST}_{\text {pre-industrial }}=\text { HadISST }_{1870-1900} \\
& - \text { ModernSST }_{\text {PRISM }}+\text { ModernSST }_{\text {Local }}
\end{aligned}
$$

Pre-industrial sea-ice area is identical to its local modern match.

The generation of mid-Pliocene SST and sea-ice forcing (Fig. 1c and f) follows as well the anomaly method (Eq. 2) described by Haywood et al. (2010).

$$
\begin{aligned}
& \mathrm{SST}_{\text {mid-Pliocene }}=\text { mid-PlioceneSST } \\
& - \text { ModernSSM }_{\text {PRISM }}+\text { ModernSST }_{\text {Local }}
\end{aligned}
$$

Sea ice area follows the mid-Pliocene monthly SSTs. Where SST is higher than $-1.8^{\circ} \mathrm{C}$, the sea ice coverage is set to 0 .

\subsection{Land-sea mask and topography}

Following the PlioMIP experimental guidelines (Haywood, et al., 2010), the reference experiment uses the local modern land-sea mask and topography conditions. The mid-Pliocene land-sea mask equals the local modern condition. It is the same mask as that used in the coupled simulation (Zhang et al., 2012). The mid-Pliocene topography is based on the PRISM topography file topo_v1.3 (Sohl et al., 2009), and created with the anomaly method (Fig. 2, Eq. 3).

$$
\begin{gathered}
\text { Topo }_{\text {mid-Pliocene }}=\text { mid-PlioceneTopo } \\
\text { PRISM } \\
- \text { ModernTopo }_{\text {PRISM }}+\text { ModernTopo }_{\text {Local }}
\end{gathered}
$$

Compared to the modern topography (Fig. 2b), large changes in mid-Pliocene topography appear in particular on 

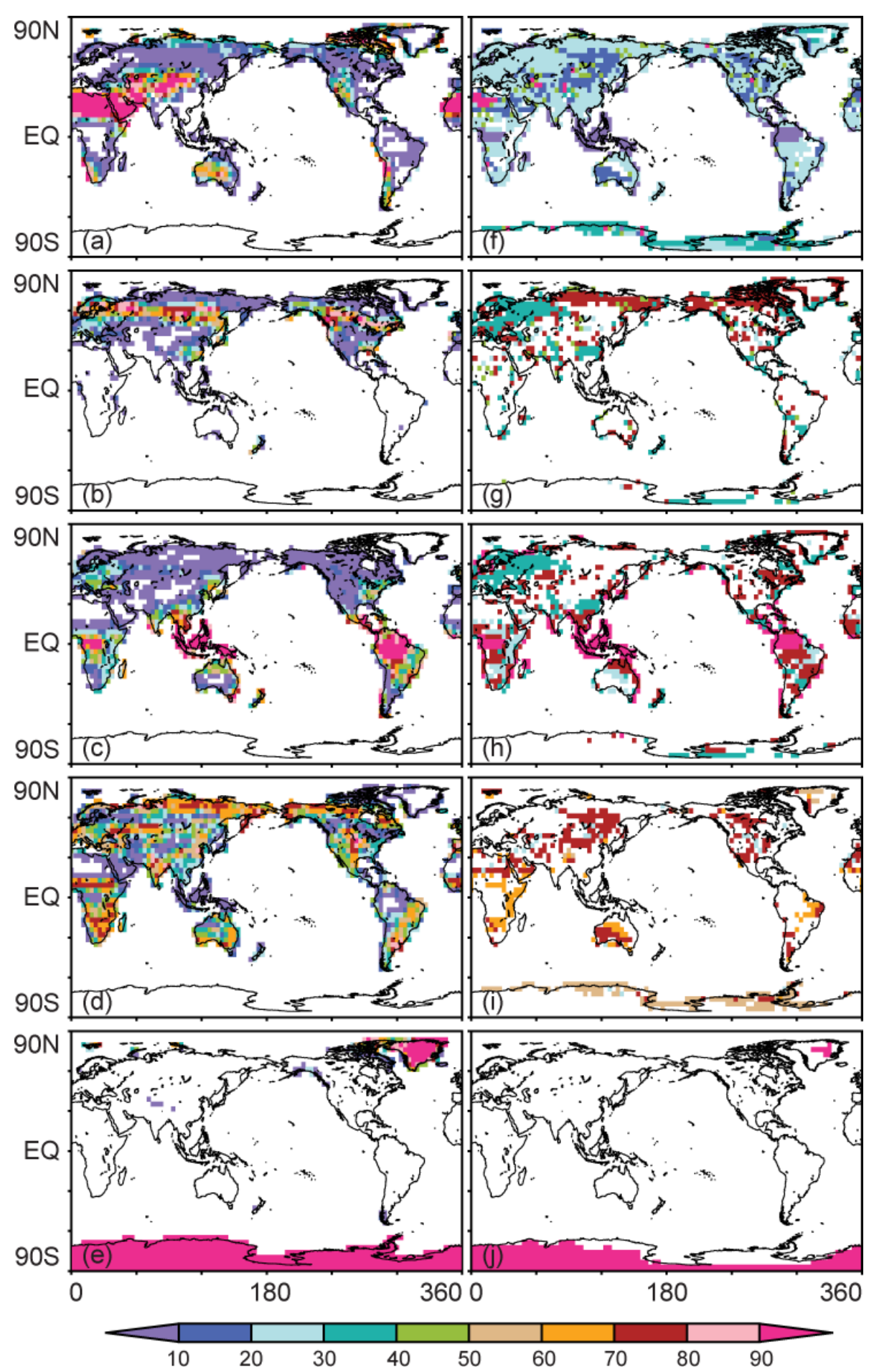

Fig. 3. Pre-industrial and mid-Pliocene land cover conditions (\%), left column for the pre-industrial, right column for the mid-Pliocene. (a) and (f) for the percentage of bare land. (b) and (g) for the percentage of needleleaf trees, including needleleaf evergreen temperate tree, needleleaf evergreen boreal tree, and needleleaf deciduous boreal tree. (c) and (h) for the percentage of broadleaf trees, including broadleaf evergreen tropical tree, broadleaf evergreen temperate tree, broadleaf deciduous tropical tree, broadleaf deciduous temperate tree, and broadleaf deciduous boreal tree. (d) and (i) for the percentage of shrubs and grasses, including broadleaf evergreen temperate shrub, broadleaf deciduous temperate shrub, broadleaf deciduous boreal shrub, arctic C3 grass, cool C3 grass, warm C4 grass, and crop. (e) and (j) for the percentage of land ice. 
Greenland and at the margin of the Antarctic because of the reconstructed retreat of ice-sheets. The Rocky and Andes mountains are higher in the mid-Pliocene topography.

\subsection{Vegetation and ice-sheet}

Following the PlioMIP experimental guidelines (Haywood, et al., 2010), the pre-industrial experiment uses the vegetation and ice-sheet conditions (Fig. 3) for year 1850. The mid-Pliocene vegetation and ice sheet conditions are created based on the PRISM condition biome_veg_v1.2 (Hill et al., 2007; Salzmann et al., 2008). Firstly, it is changed to the LSM (Land System Model) vegetation types (https://wiki. ucar.edu/display/paleo/Biome4+conversion+to+LSM), and then converted to PFTs (Plant Function Types, http://www. cgd.ucar.edu/ccr/paleo/Notes/lsm2clm.txt). Compared to the pre-industrial vegetation, in the mid-Pliocene simulation, the percentage of bare land is reduced, while the percentage of trees increases (Fig. 3). The mid-Pliocene extent of ice-sheets is smaller on Greenland and at the margin of the Antarctic. The vegetation and ice-sheet conditions used in this study are identical to those used in Experiments II with NorESML (Zhang et al., 2012).

\subsection{Experimental design}

With the above described conditions, we design three experiments here: the pre-industrial experiment, the control experiment, and the mid-Pliocene experiment (Table 1). The control experiment is the reference experiment as suggested by the PlioMIP experimental guidelines. These three experiments are run for $50 \mathrm{yr}$. Time series of global mean SAT are shown in Fig. 4a. Other results described below are based on climatological means from the last $20 \mathrm{yr}$ of each simulation. These climatological means are similar to the means of the last $30 \mathrm{yr}$ of each experiment, which are suggested by the PlioMIP experimental guidelines.

\section{Results}

\subsection{Pre-industrial and control experiment}

\subsubsection{SAT}

For the pre-industrial experiment, the global mean annual SAT is $14.4^{\circ} \mathrm{C}$. It is $0.2^{\circ} \mathrm{C}$ colder than the global mean annual SAT $\left(14.6^{\circ} \mathrm{C}\right)$ in the control experiment (Fig. 4a, Table 2). Both simulations are warmer than the estimation of the pre-industrial SAT (about $13.5^{\circ} \mathrm{C}$, Hansen et al., 2010), and close to the modern global mean annual SAT.

The simulated zonal mean annual SAT (Fig. 4b) is similar in the pre-industrial and in the control experiment. The results agree with the zonal mean annually averaged EARinterim temperature between 1979 and 2008 (Dee et al., 2011), in particular in the low and middle latitudes of both
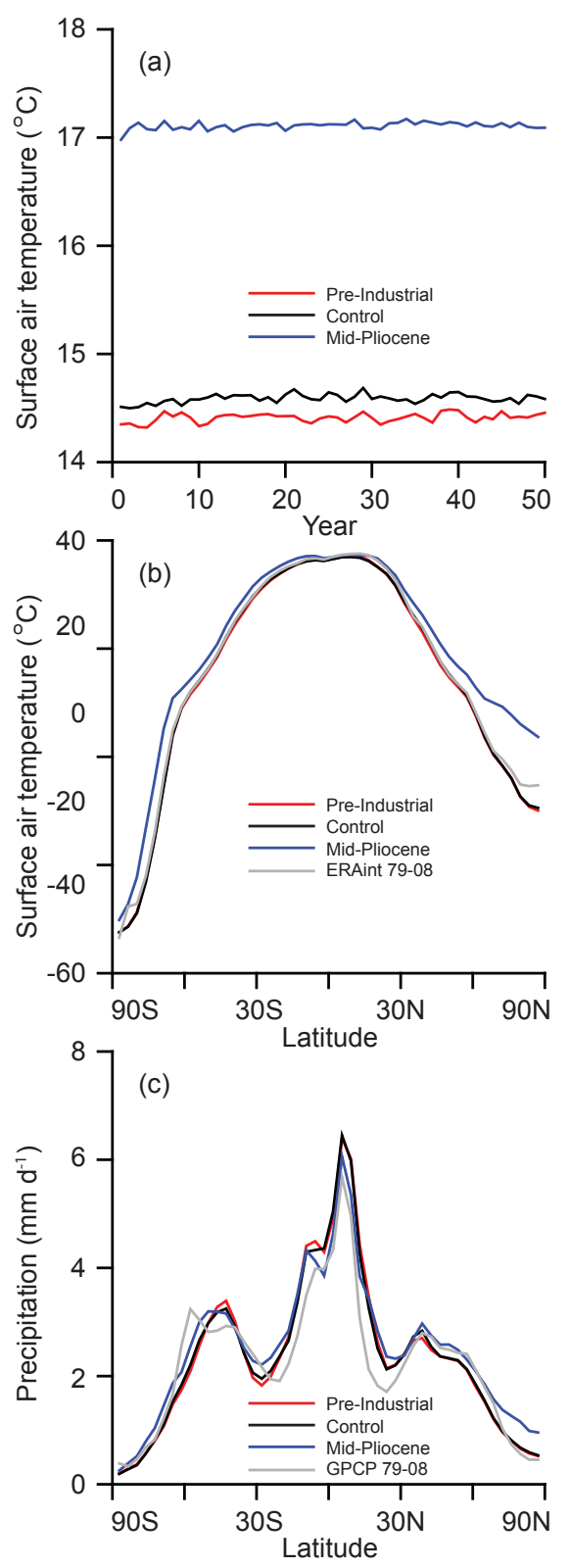

Fig. 4. (a) Time series of SAT $\left({ }^{\circ} \mathrm{C}\right)$ in the pre-industrial (red line), the control (black line), and the mid-Pliocene (blue line) experiment. (b) Simulated zonal mean annual SAT $\left({ }^{\circ} \mathrm{C}\right)$, with comparison to the ERA-interim temperature from 1979 to 2008. (c) Simulated zonal mean annual precipitation $\left(\mathrm{mm} \mathrm{d}^{-1}\right)$, with comparison to the Global Precipitation Climatology Project (GPCP) 1979-2008 precipitation.

hemispheres, though the discrepancy looks relatively large close to the Poles.

The simulated annual SAT fields show the same pattern in the pre-industrial (Fig. 5a) and the control experiment (Fig. 5b). The highest SAT appears over the western tropical Pacific Ocean and the Indian Ocean, where the annual SAT is higher than $28^{\circ} \mathrm{C}$. The coldest SAT occurs in 
Table 1. Boundary conditions for the pre-industrial, the control and the mid-Pliocene experiment.

\begin{tabular}{llll}
\hline Conditions & Pre-Industrial & Control & Mid-Pliocene \\
\hline Land-sea mask & Local modern & Local modern & Local modern \\
Topography & Local modern & Local modern & PRISM Topo ano. + local modern \\
$\mathrm{SST}$ & HadISST ano. + local modern & Local modern & PRISM SST ano. + local modern \\
$\mathrm{CO}_{2}$ & $280 \mathrm{ppm}$ & $280 \mathrm{ppm}$ & $405 \mathrm{ppm}$ \\
$\mathrm{N}_{2} \mathrm{O}$ & $270 \mathrm{ppb}$ & $270 \mathrm{ppb}$ & $270 \mathrm{ppb}$ \\
$\mathrm{CH}$ & $760 \mathrm{ppb}$ & $760 \mathrm{ppb}$ & $760 \mathrm{ppb}$ \\
$\mathrm{CFCs}$ & 0 & 0 & 0 \\
Solar constant & $1370 \mathrm{~W} \mathrm{~m}^{-2}$ & $1370 \mathrm{~W} \mathrm{~m}^{-2}$ & $1370 \mathrm{~W} \mathrm{~m}^{-2}$ \\
Vegetation & Local pre-industrial & Local pre-industrial & PRISM vegetation \\
Orbital parameters & Year 1950 & Year 1950 & Year 1950 \\
\hline
\end{tabular}

Table 2. Globally averaged climatology for the pre-industrial, the control and the mid-Pliocene experiment

\begin{tabular}{lrrr}
\hline Exp. & Pre-industrial & Control & Mid-Pliocene \\
\hline Top energy balance & $-3.97 \mathrm{~W} \mathrm{~m}^{-2}$ & $-3.17 \mathrm{~W} \mathrm{~m}^{-2}$ & $0.39 \mathrm{~W} \mathrm{~m}^{-2}$ \\
Surface air temperature & $14.4^{\circ} \mathrm{C}$ & $14.6^{\circ} \mathrm{C}$ & $17.1^{\circ} \mathrm{C}$ \\
Precipitation & $2.9 \mathrm{~mm} \mathrm{~d}^{-1}$ & $2.9 \mathrm{~mm} \mathrm{~d}^{-1}$ & $3.0 \mathrm{~mm} \mathrm{~d}^{-1}$ \\
\hline
\end{tabular}

the Antarctic, where the annual SAT is lower than $-50^{\circ} \mathrm{C}$. Such a pattern is in agreement with the ERA-interim annual temperature fields (Fig. 5c, Dee et al., 2011).

\subsubsection{Precipitation}

In the pre-industrial experiment, the global mean annual precipitation is $2.9 \mathrm{~mm} \mathrm{~d}^{-1}$ (Table 2). It is the same as the global mean annual precipitation in the control experiment. In these two experiments, highest zonal mean annual precipitation appears in the Intertropical Convergence Zone (ITCZ), at about $6.5 \mathrm{~mm} \mathrm{~d}^{-1}$ (Fig. 4c). At the Poles, zonal mean annual precipitation is low, at about $0.2 \mathrm{~mm} \mathrm{~d}^{-1}$ at the South Pole and about $0.5 \mathrm{~mm} \mathrm{~d}^{-1}$ at the North Pole. The simulated zonal mean annual precipitation matches the zonal mean of observed precipitation from the Global Precipitation Climatology Project (GPCP; Adler et al., 2003) averaged over the period 1979-2008. The overall pattern and amount of simulated global precipitation agree with the observations (Fig. 5d-f).

However, large discrepancies of annual precipitation between the simulations and the observation appear in the tropics. The simulations overestimate the annual precipitation over e.g. the Arabian Sea, the South China Sea, the tropical Pacific in the Northern Hemisphere and East Asia; and underestimate the annual precipitation over e.g. the Indian Ocean and the tropical Pacific in the Southern Hemisphere.

\subsection{Mid-Pliocene experiment}

\subsubsection{SAT}

In the mid-Pliocene experiment, the global mean annual SAT is $17.1^{\circ} \mathrm{C}$ (Table 2). It is $2.7^{\circ} \mathrm{C}$ warmer than the preindustrial experiment, and $2.5^{\circ} \mathrm{C}$ warmer than the control experiment. Compared to the pre-industrial or the control experiment, stronger warming appears in the high latitudes of both hemispheres, whereas weak cooling occurs in the tropics of the mid-Pliocene experiment (Fig. 6). Near the Equator, the zonal mean annual SAT increases only by $1^{\circ} \mathrm{C}$. At high latitudes of the Southern Hemisphere, the zonal mean annual SAT increases by $11^{\circ} \mathrm{C}$. Largest warming appears near the North Pole, where the zonal mean annual SAT increases by $13{ }^{\circ} \mathrm{C}$. Such changes, with stronger warming at high latitudes, follow the mid-Pliocene SST anomalies reconstructed by the PRISM (Dowsett et al., 2009), and also agree with PlioMIP simulations of other groups (e.g. Chan et al., 2011; Koenig et al., 2012; Yan et al., 2012; Kamae and Ueda, 2012; Contoux et al., 2012).

Stronger warming at high latitudes can also be observed in the seasonal SAT anomalies, in particular in winter. In boreal winter, zonal mean SAT over the Arctic in the midPliocene experiment increases by $21^{\circ} \mathrm{C}$ relative to the preindustrial experiment, and by $19^{\circ} \mathrm{C}$ relative to the control experiment (Fig. 6). In austral winter, zonal mean SAT at the margin of the Antarctic in the mid-Pliocene experiment increases by $16^{\circ} \mathrm{C}$ relative to the pre-industrial or the control experiment. 

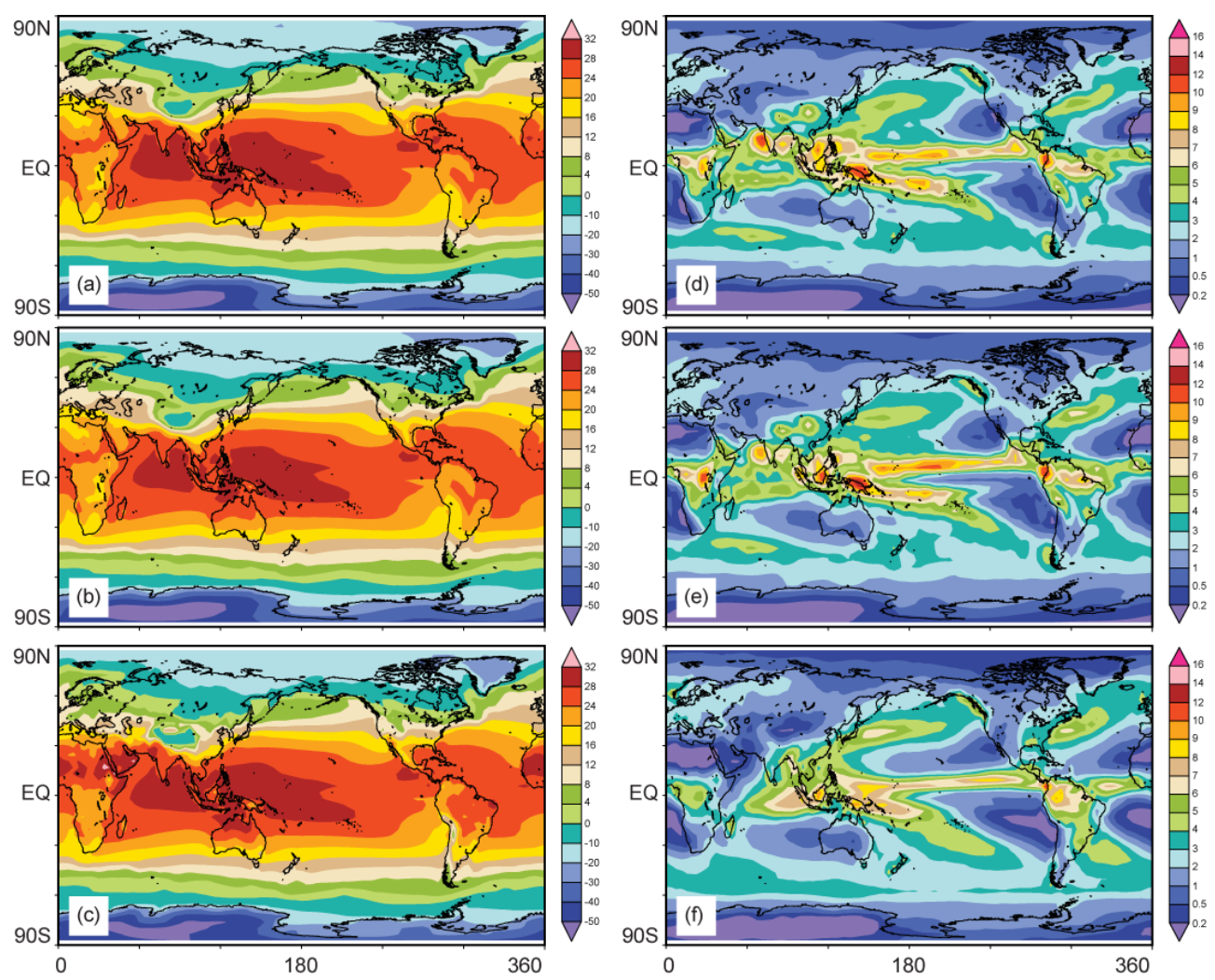

Fig. 5. Global annual SAT (left column, ${ }^{\circ} \mathrm{C}$ ) and precipitation (right column, $\mathrm{mm} \mathrm{d}^{-1}$ ) simulated in the pre-industrial (a, d), and the control (b, e) experiment, with comparison to the ERA-interim 1979-2008 SAT (c) and GPCP 1979-2008 precipitation (f) .

\subsubsection{Precipitation}

In the mid-Pliocene experiment, the global mean annual precipitation is $3.0 \mathrm{~mm} \mathrm{~d}^{-1}$ (Table 2). It is $0.1 \mathrm{~mm} \mathrm{~d}^{-1}$ larger than the global mean annual precipitation simulated in the pre-industrial and the control experiment.

The zonal mean mid-Pliocene annual precipitation decreases in the tropics by $0.7 \mathrm{~mm} \mathrm{~d}^{-1}$ relative to the preindustrial experiment, and by $0.6 \mathrm{~mm} \mathrm{~d}^{-1}$ relative to the control experiment (Fig. 4c and Fig. 7). At tropics, the changes in precipitation have large regional variations. On the global precipitation anomaly map, larger annual precipitation increments $\left(>3 \mathrm{~mm} \mathrm{~d}^{-1}\right)$ appear over the north Arabian Sea (on the coast of the Arabian Peninsula), tropical Africa, and the west coast of tropical South America. Larger decreases in annual precipitation $\left(<-3 \mathrm{~mm} \mathrm{~d}^{-1}\right)$ appear over the Indian Subcontinent, the South China Sea, the Bismarck Sea (on the north coast of the island of New Guinea), and the tropical Pacific on the coast of Central America (Fig. 7).

At middle and high latitudes of both hemispheres, the zonal mean annual precipitation increases by about $0.5 \mathrm{~mm} \mathrm{~d}^{-1}$. The changes of precipitation have less regional variations in the middle and high latitudes relative to in the tropics. The largest annual precipitation increment occurs over the Norwegian Sea $\left(4 \mathrm{~mm} \mathrm{~d}^{-1}\right)$, where the SSTs are remarkably larger in the PRISM mid-Pliocene reconstructions (Dowsett et al., 2009).

The mid-Pliocene anomalies of global mean precipitation do not depend strongly on the choice of the reference simulation (i.e. the pre-industrial simulation or the control simulation). However, apparent discrepancies exist in regional precipitation anomalies. For example over the Indian Subcontinent or the Indonesian archipelago, the simulated midPliocene boreal summer precipitation decreases by $4 \mathrm{~mm} \mathrm{~d}^{-1}$ relative to the control experiment, but decreases by $6 \mathrm{~mm} \mathrm{~d}^{-1}$ relative to the pre-industrial experiment.

\section{Discussion and summary}

As described above, the simulated temperature and precipitation in the pre-industrial and the control experiment both agree with modern observations. The simulated midPliocene climate is warmer than the pre-industrial and the control experiment, in particular in the high latitudes and during the winter season. The simulated general patterns of mid-Pliocene warming agree with our earlier coupled simulations (Zhang et al., 2012), and also simulations from other PlioMIP groups (e.g. Chan et al., 2011; Koenig et al., 2012; Yan et al., 2012; Zhang et al., 2012; Kamae and Ueda, 2012; Contoux et al., 2012). 


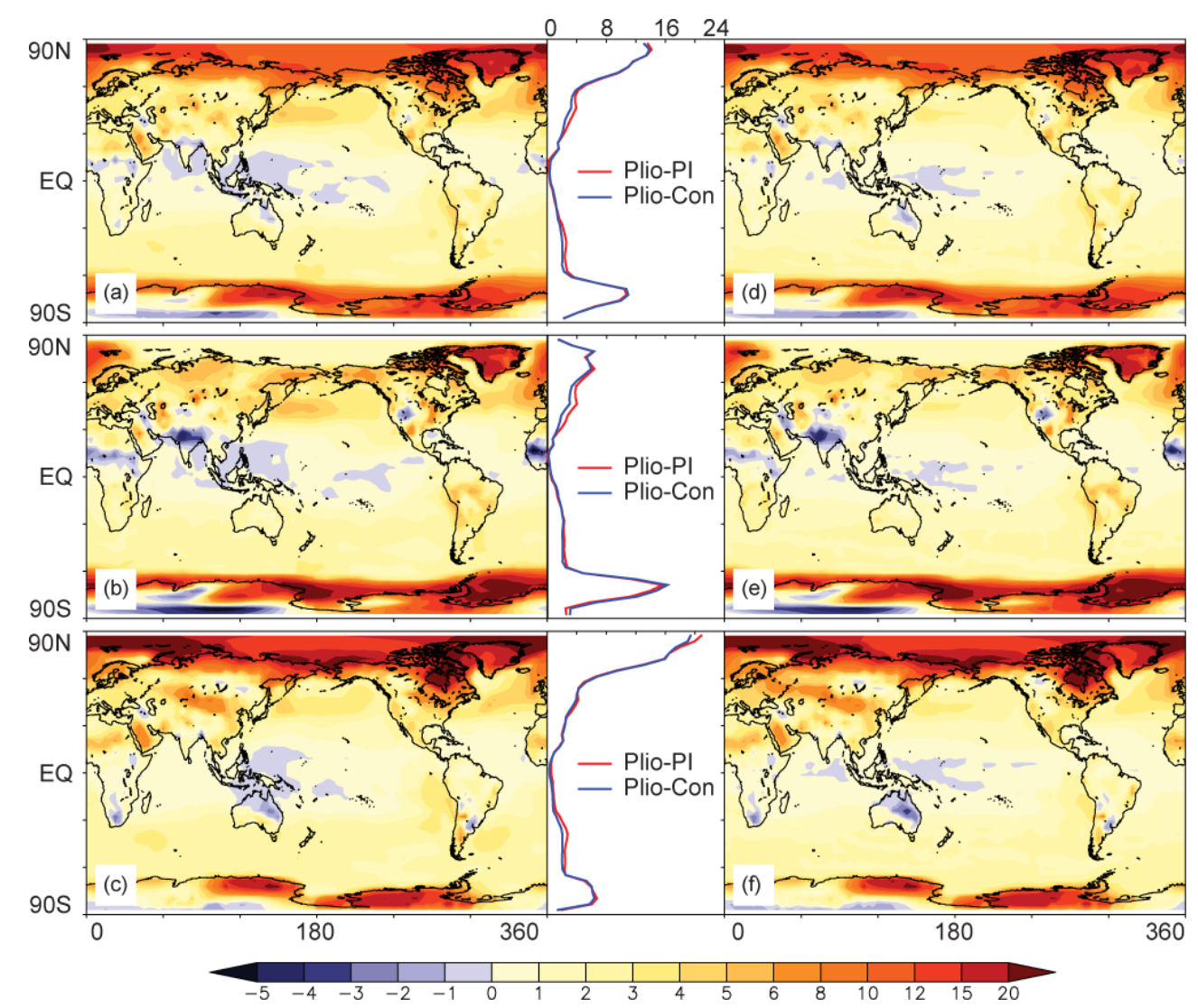

Fig. 6. SAT anomalies $\left({ }^{\circ} \mathrm{C}\right)$, left column for the anomalies between the mid-Pliocene and the pre-industrial experiment, right column for the anomalies between the mid-Pliocene and the control experiment. (a) and (d) for annual mean, (b) and (e) for boreal summer, and (c) and (f) for boreal winter. The bold lines in the middle show zonal mean values for these anomalies.

The analysis of mid-Pliocene climate anomalies necessitates a reference experiment. In our study, if the control experiment is chosen to be the reference, as the PlioMIP experimental guidelines suggest, the mid-Pliocene global mean annual SAT increases by $2.5^{\circ} \mathrm{C}$. If on the other hand the pre-industrial experiment is chosen as the reference, the midPliocene global mean annual SAT increases by $2.7^{\circ} \mathrm{C}$, which is $8 \%$ larger. This difference is not large, and to some extent can be neglected on a global scale.

On a regional scale, however, the choice of the reference simulation clearly influences the mid-Pliocene climate anomalies (Fig. 8). For example, if the pre-industrial experiment is chosen as the reference (instead of the control experiment), the mid-Pliocene zonal mean annual SAT anomalies are increased (decreased) by $30 \%(55 \%)$ at middle (low) latitudes. Over the Indian Subcontinent, the simulated midPliocene boreal summer precipitation reduction is further enlarged by $50 \%$, when the pre-industrial experiment is chosen to be the reference (Fig. 7).

The PlioMIP experimental guidelines suggest employing local modern SST fields in the reference experiment for Experiments I. The mid-Pliocene SST forcing is created according to the anomaly method, in which the PRISM mid-
Pliocene SST anomalies are added on the local modern SST fields (i.e. group-specific). This experiment design is useful for calculation of climate sensitivity considering the PRISM mid-Pliocene SST anomalies. It is also a common basis for future comparisons of PlioMIP AGCM simulations.

However, it should be noted that, compared to the PlioMIP AOGCM simulations (Experiments II), the mid-Pliocene climate anomalies may be underestimated in the PlioMIP AGCM simulations (Experiments I). All PlioMIP AGCM simulations use modern SSTs in reference experiments, but all AOGCM experiments use pre-industrial simulations as reference experiments. We indeed find a difference between our AGCM and AOGCM simulations (Zhang et al., 2012), and also in the simulations carried out by Chan et al. (2011). The simulations carried out by Kamae and Ueda (2012) and Contoux et al. (2012) on the other hand do not show such differences. This issue should be noted and further assessed during the upcoming PlioMIP analysis and synthesis phase.

In summary, we describe the PlioMIP experiments I with the atmosphere component (CAM4) of the NorESM-L climate model in this paper. In accordance with the PlioMIP experimental guidelines, we carry out a mid-Pliocene experiment, and a control experiment forced by the standard 


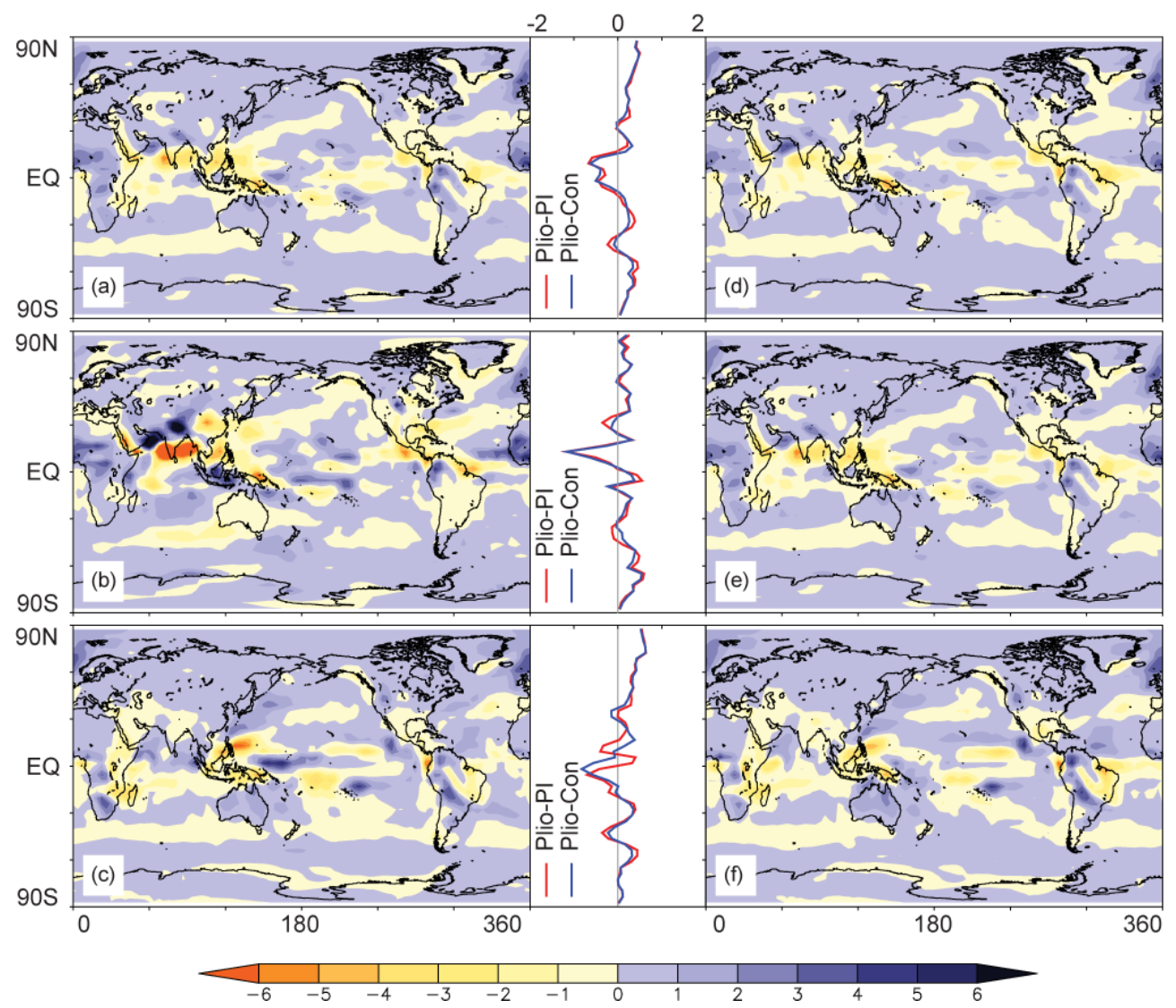

Fig. 7. Precipitation anomalies $\left(\mathrm{mm} \mathrm{d}^{-1}\right)$, left column for the anomalies between the mid-Pliocene and the pre-industrial experiment, right column for the anomalies between the mid-Pliocene and the control experiment. (a) and (d) for annual mean, (b) and (e) for boreal summer, and (c) and (f) for boreal winter. The bold lines in the middle show zonal mean values.
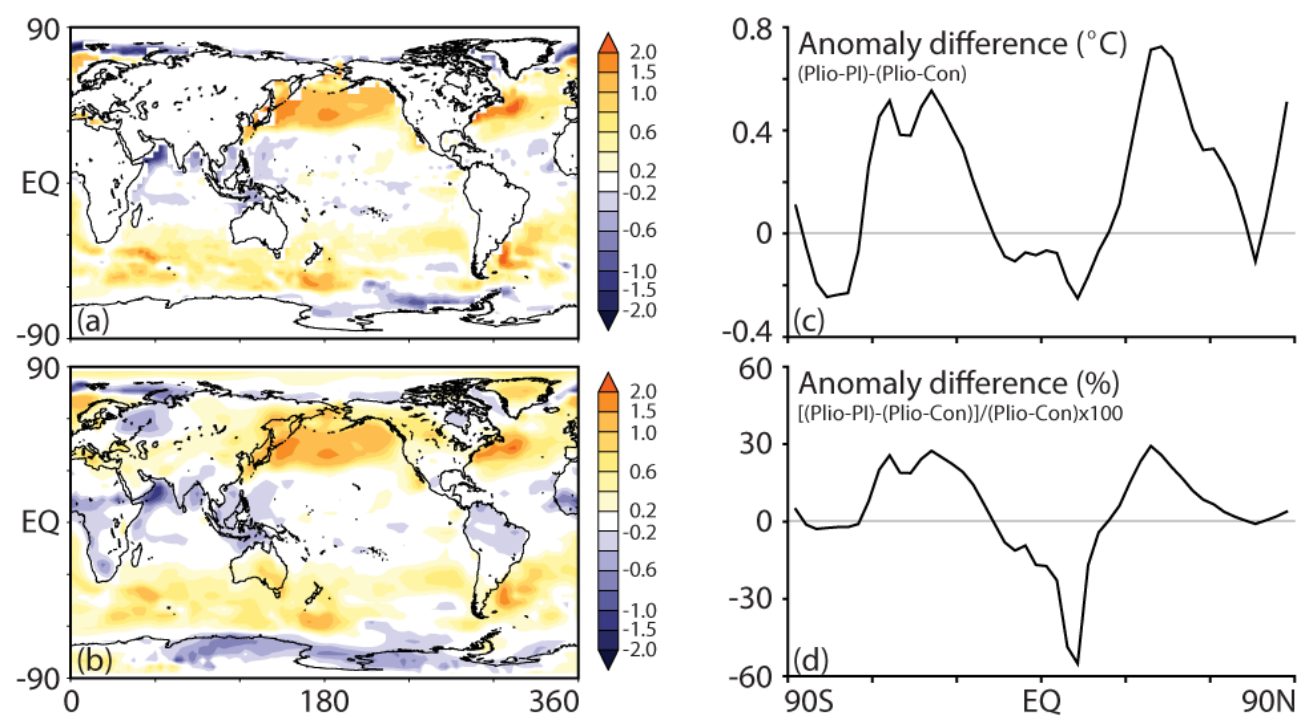

Fig. 8. Uncertainties in mid-Pliocene SAT anomalies introduced by the choice of the SST forcing. (a) Differences in annual mean SST between the local modern and the 1879-1900 HadISST. (b) Differences between the mid-Pliocene SAT anomalies relative to the preindustrial and the mid-Pliocene SAT anomalies relative to the control experiment, Fig. 6a-d. (c) The zonal mean for (b) . (d) The percentage of the zonal mean difference in (c), relative to the zonal mean SAT anomalies between the mid-Pliocene and the control experiment. 
CAM4 modern SST fields. We also carry out a pre-industrial experiment forced by the SST climatology from 1879-1900 HadISST, which is close to the pre-industrial forcing. With these three AGCM experiments, we assess potential uncertainties in analyzing mid-Pliocene climate anomalies.

Our experiments illustrate that the simulated mid-Pliocene global mean SAT is $17.1^{\circ} \mathrm{C}$. It is $2.7^{\circ} \mathrm{C}$ warmer than the preindustrial and $2.5^{\circ} \mathrm{C}$ warmer than the control experiment. Choosing modern SST forcing in the reference experiment only weakly underestimates mid-Pliocene climate anomalies on a global scale. However, on a regional scale, the potential uncertainties linked to the choice of the SST forcing for the reference simulation should be noted and assessed in the upcoming PlioMIP analyses.

Acknowledgements. We sincerely thank two anonymous reviewers for the detailed comments, which are helpful for improving the language of the paper. This study was jointly supported by the Earth System Modeling (ESM) project financed by Statoil, Norway, the National 973 Program of China (Grant No. 2010CB950102), and the National Natural Science Foundation of China (Grant No. 40902054). The NorESM development was supported by the Integrated Earth System Approach to Explore Natural Variability and Climate Sensitivity (EARTHCLIM) project, which is a nationally coordinated climate research project in Norway.

Edited by: D. Lunt

\section{References}

Adler, R. F., Huffman, G. J., Chang, A., Ferraro, R., Xie, P., Janowiak, J., Rudolf, B., Schneider, U., Curtis, S., Bolvin, D., Gruber, A., Susskind, J., and Arkin, P.: The Version 2 Global Precipitation Climatology Project (GPCP) Monthly Precipitation Analysis (1979-Present), J. Hydrometeor., 4, 1147-1167, 2003.

Alterskjær, K., Kristjánsson, J. E., and Seland, Ø.: Sensitivity to deliberate sea salt seeding of marine clouds - observations and model simulations, Atmos. Chem. Phys., 12, 2795-2807, doi:10.5194/acp-12-2795-2012, 2012.

Chan, W.-L., Abe-Ouchi, A., and Ohgaito, R.: Simulating the midPliocene climate with the MIROC general circulation model: experimental design and initial results, Geosci. Model Dev., 4, 1035-1049, doi:10.5194/gmd-4-1035-2011, 2011.

Chandler, M., Rind, D., and Thompson, R.: Joint investigations of the middle Pliocene climate II: GISS GCM Northern Hemisphere results, Global Planet. Change, 9, 197-219, 1994.

Contoux, C., Ramstein, G., and Jost, A.: Modelling the midPliocene Warm Period climate with the IPSL coupled model and its atmospheric component LMDZ5A, Geosci. Model Dev., 5, 903-917, doi:10.5194/gmd-5-903-2012, 2012.

Dee, D. P., Uppala, S. M., Simmons, A. J., Berrisford, P., Poli, P., Kobayashi, S.,Andrae, U., Balmaseda, M.A, Balsamo, G., Bauer, P., Bechtold, P., Beljaars, A. C. M., van de Berg, L., Bidlot, J., Bormann, N., Delsol, C., Dragani, R., Fuentes, M., Geer, A. J., Haimberger, L., Healy, S. B., Hersbach, H., Hólm, E. V., Isaksen, L., Kållberg, P., Köhler, M., Matricardi, M., McNally, A. P., Monge-Sanz, B. M., Morcrette, J. J., Park, B. K., Peubey, C., de Rosnay, P., Tavolato, C., Thépaut, J. N., Vitart, F.: The ERAInterim reanalysis: configuration and performance of the data assimilation system, Q. J. Roy. Meteor. Soc., 137, 553-597, 2011.

Dowsett, H. J., Cronin, T. M., Poore, R. Z., Thompson, R. S., Whatley, R. C., and Haywood, A. M.: Micropaleontological evidence for increased meridional heat transport in the North Atlantic Ocean during the Pliocene, Science, 258, 1133-1135, 1992.

Dowsett, H. J., Thompson, R., Barron, J., Cronin, T., Fleming, F., Ishman, S., Poore, R., Willard, D., and Holtz, T.: Joint Investigations of the Middle Pliocene Climate I: PRISM Paleoenvironmental Reconstructions, Global Planet. Change, 9, 169-195, 1994.

Dowsett, H. J., Barron, J., and Poore, R.: Middle Pliocene sea surface temperatures: a global reconstruction, Mar. Micropaleontol., 27, 13-25, 1996.

Dowsett, H. J., Barron, J. A., Poore, R. Z., Thompson, R. S., Cronin, T. M., Ishman, S. E., and Willard, D. A.: Middle Pliocene paleoenvironmental reconstruction: PRISM2, US Geol. Surv., Open File Rep., 99-535, 1999.

Dowsett, H. J., Robinson, M. M., and Foley, K. M.: Pliocene threedimensional global ocean temperature reconstruction, Clim. Past, 5, 769-783, doi:10.5194/cp-5-769-2009, 2009.

Dowsett, H. J., Robinson, M. M., Haywood, A. M., Salzmann, U., Hill, D., Sohl, L., Chandler, M., Williams, M., Foley, K., and Stoll, D.: The PRISM3D paleoenvironmental reconstruction, Stratigraphy, 7, 123-139, 2010.

Eaton, B.: User's Guide to the Community Atmosphere Model CAM-4.0. http://www.cesm.ucar.edu/models/ccsm4.0/cam/ docs/users_guide/ug.html, (last access: December 2011), 2010.

Hansen, J., Ruedy, R., Sato, M., and Lo, K.: Global surface temperature change, Rev. Geophys., 48, RG4004, doi:10.1029/2010RG000345, 2010.

Haywood, A. M. and Valdes, P. J.: Modelling Pliocene warmth: contribution of atmosphere, oceans and cryosphere, Earth Planet. Sci. Lett., 218, 363-377, 2004.

Haywood, A. M., Valdes, P. J., and Sellwood, B. W.: Global scale palaeoclimate reconstruction of the middle Pliocene climate using the UKMO GCM: initial results, Global Planet. Change, 25, 239-256, 2000.

Haywood, A. M., Dowsett, H. J., Otto-Bliesner, B., Chandler, M. A., Dolan, A. M., Hill, D. J., Lunt, D. J., Robinson, M. M., Rosenbloom, N., Salzmann, U., and Sohl, L. E.: Pliocene Model Intercomparison Project (PlioMIP): experimental design and boundary conditions (Experiment 1), Geosci. Model Dev., 3, 227-242, doi:10.5194/gmd-3-227-2010, 2010.

Haywood, A. M., Dowsett, H. J., Robinson, M. M., Stoll, D. K., Dolan, A. M., Lunt, D. J., Otto-Bliesner, B., and Chandler, M. A.: Pliocene Model Intercomparison Project (PlioMIP): experimental design and boundary conditions (Experiment 2), Geosci. Model Dev., 4, 571-577, doi:10.5194/gmd-4-571-2011, 2011.

Hill, D. J., Haywood, A. M., Hindmarsh, R. C. A. and Valdes, P. J.: Characterising ice sheets during the mid Pliocene: evidence from data and models, in: Deep time perspectives on climate change: Marrying the signal from computer models and biological proxies, edited by: Williams, M., Haywood, A. M., Gregory, F. J., and Schmidt, D. N., the Micropalaeontological Society, Special Publications, the Geological Society, London, 517-538, 2007.

Hurrell, J.: hurrell_sst_ifrac.1x1.050606.nc, available at: https://svn-ccsm-inputdata.cgd.ucar.edu/trunk/inputdata/ocn/ 
docn7/SSTDATA/, (last access: March 2011), 2005.

Jansen, E., Overpeck, J., Briffa, K.R., Duplessy, J.-C., Joos, F., Masson-Delmotte, V., Olago, D., Otto-Bliesner, B., Peltier, W.R., Rahmstorf, S., Ramesh, R., Raynaud, D., Rind, D., Solomina, O., Villalba, R., and Zhang, D.: Palaeoclimate, in: Climate Change 2007: The Physical Science Basis. Contribution of Working Group I to the Fourth Assessment Report of the Intergovernmental Panel on Climate Change, edited by: Solomon, S., Qin, D., Manning, M., Chen, Z., Marquis, M., Averyt, K. B., Tignor, M., and Miller, H. L., Cambridge University Press, Cambridge, UK and New York, NY, USA, 2007.

Jiang, D., Wang, H., Ding, Z., Lang, X., and Drange, H.: Modeling the middle Pliocene climate with a global atmospheric general circulation model, J. Geophys. Res., 110, D14107, doi:10.1029/2004JD005639, 2005.

Kamae, Y. and Ueda, H.: Mid-Pliocene global climate simulation with MRI-CGCM2.3: set-up and initial results of PlioMIP Experiments 1 and 2, Geosci. Model Dev., 5, 793-808, doi:10.5194/gmd-5-793-2012, 2012.

Koenig, S. J., DeConto, R. M., and Pollard, D.: Pliocene Model Intercomparison Project Experiment 1: implementation strategy and mid-Pliocene global climatology using GENESIS v3.0 GCM, Geosci. Model Dev., 5, 73-85, doi:10.5194/gmd-5-732012, 2012.

Lunt, D. J., Haywood, A. M., Schmidt, G. A., Salzmann, U., Valdes, P. J., and Dowsett, H. J.: Earth system sensitivity inferred from Pliocene modelling and data, Nat. Geosci. 3, 60-64, 2010.

Lunt, D. J., Haywood A. M., Schmidt, G. A., Salzmann, U., Valdes, P. J., and Dowsett, H. J.: On the causes of mid-Pliocene warmth and polar amplification, Earth Planet. Sci. Lett., 321-322, 128138, 2012.

Meehl, G. A., Stocker, T. F., Collins, W. D., Friedlingstein, P., Gaye, A. T., Gregory, J. M., Kitoh, A., Knutti, R., Murphy, J. M., Noda, A., Raper, S. C. B., Watterson, I. G., Weaver, A. J., and Zhao, Z. C.: Global climate projections, in: Climate Change 2007: The Physical Science Basis, Contribution of Working Group I to the Fourth Assessment Report of the Intergovernmental Panel on Climate Change, edited by: Solomon, S., Qin, D., Manning, M., Chen, Z., Marquis, M., Averyt, K. B., Tignor, M., Miller, H. L., Cambridge University Press, Cambridge, UK and New York, NY, USA, 770-772, 2007.
Neale, R. B., Richter, J. H., Conley, A. J., Park, S., Lauritzen, P. H., Gettelman, A., Williamson, D. L., Rasch, P. J., Vavrus, S. J., Taylor, M. A., Collins, W. D., Zhang, M., and Lin, S.: Description of the NCAR Community Atmosphere Model (CAM 4.0), NCAR technical note, NCAR/TN-485+STR, 2010.

Pagani, M., Liu, Z., LaRiviera, J., and Ravelo, A. C.: High climate sensitivity to atmospheric carbon dioxide for the past 5 million years, Nat. Geosci., 3, 27-30, 2009.

Salzmann, U., Haywood, A. M., Lunt, D. J., Valdes, P. J., and Hill, D. J.: A new global biome reconstruction and data-model comparison for the Middle Pliocene, Global Eco. Biogeogr., 17, 432447, 2008.

Shields, C. A., Bailey, D. A., Danabasoglu, G., Jochum, M., Kiehl, J. T., Levis, S., and Park, S.: The Low Resolution CCSM4, J. Climate, 25, 3993-4014, doi:10.1175/JCLI-D-11-00260.1, 2012.

Sloan, L. C., Crowley, T. J., and Pollard, D.: Modeling of middle Pliocene climate with the NCAR GENESIS general circulation model, Mar. Micropaleontol., 27, 51-61, 1996.

Sohl, L. E., Chandler, M. A., Schmunk, R. B., Mankoff, K., Jonas, J. A., Foley, K. M., and Dowsett, H. J.: PRISM3/GISS topographic reconstruction: U.S. Geol.1 Surv. Data Series 419, 6 pp., 2009.

Watanabe, T., Suzuki, A., Minobe, S., Kawashima, T., Kameo, K., Minoshima, K., Aguilar, Y. M., Wani, R., Kawahata, H., Sowa, K., Nagai, T., and Kase, T.: Permanent El Niño during the Pliocene warm period not supported by coral evidence, Nature, 471, 209-211, 2011.

Yan, Q., Zhang, Z., Wang, H., Jiang, D. and Zheng, W.: Simulation of sea surface temperature changes in the Middle Pliocene warm period and comparison with reconstructions, Chinese Sci. Bull., 56, 890-899, 2011.

Yan, Q., Zhang, Z. S., Wang, H. J., Gao, Y. Q., and Zheng, W. P.: Set-up and preliminary results of mid-Pliocene climate simulations with CAM3.1, Geosci. Model Dev., 5, 289-297, doi:10.5194/gmd-5-289-2012, 2012.

Zhang, Z. and Yan, Q.: Pre-industrial and mid-Pliocene simulations with NorESM-L - AGCM simulations, Geosci. Model Dev. Discuss., 5, 1203-1227, doi:10.5194/gmdd-5-1203-2012, 2012. 